\title{
New Attitudes in Nigeria
}

\section{John Henshaw and Gilbert S. Child}

The importance of wildlife as a source of meat, as well as tourist revenue, is the most telling argument for its protection in Nigeria, where bushmeat is highly valued. Many species have been seriously overhunted, but populations could be built up again. The creation of a wildlife division in the Forestry Department last year was a major step in the right direction and 29 new reserves are planned. Animal numbers are increasing noticeably in the two major existing reserves, Yankari and Borgu.

In 1970 Nigeria took a significant step towards improving the administration and development of its wildlife resources when the Federal Department of Forestry announced its intention to create a Division of Wildlife and Conservation.

Under the British Administration and in the first few years after Independence, wildlife had received little attention. Uncontrolled hunting throughout the country significantly reduced both the range and abundance of many game animal species, although some species, due to their natural productivity and resilience to hunting pressure, survived at exploitable levels. Forest-living species of duiker, for instance, provide a perennial reservoir of much needed protein for the people of southern Nigeria. In 1955/56 bushmeat comprised 19 per cent of the total value of all animal protein sold in the southern regions of Nigeria (Charter, 1970), compared with 21 per cent for domestic animals and 60 per cent for fish. Moreover, the export value of wild animal skins was higher than that of cattle hides. If the wildlife contribution is significant even when it is depleted, clearly, with modern methods of management, it could become a major source of protein. There are still many parts of Nigeria where wildlife populations could be increased and managed as a protein resource without undue conflict with other forms of land use. In most areas the wild herbivore populations are well below the carrying capacity and the yield below its optimum. The experience of other African states in managing their wildlife for protein production or as a tourist resource has excited much attention in Nigeria, and forestry agencies of the Federal and State governments are now searching for ways to exploit these potentials.

To government departments, wildlife cropping on a sustained and optimum yield basis is perhaps the greatest incentive for developing wildlife management schemes, and the recent increase in game reserves, both gazetted and proposed, reflects the wide interest in this area. Most of the new game reserves were formerly forest reserves, but now wildlife will be given first consideration, before forestry, in the

John Henshaw is FAO Wildtife Ecologist, Forestry Department, University of Ibadan, Nigeria; Gilbert Child is FAO Wildlife Ecologist, Kainji Lake Research Project, New Bussa, Nigeria. 
management of most of them. It is generally accepted that game populations must be effectively protected and increase significantly before wildlife management projects can become viable in these new reserves.

Although the attraction of wildlife as a tourist resource may never be as great in Nigeria as it is in East Africa, the demands of tourism in tropical Africa are expanding and a number of West African countries are competing in this field. National parks such as Waza in Cameroun and Niokolo-Koba in Senegal attract an increasing flow of tourists, particularly from Germany and France. Because West Africa is closer to western Europe and the United States than East Africa, there is a big potential for cheaper tours.

Ecologists and sub-professional staff trained in wildlife management are urgently needed. Students are being sent to the College of African Wildlife Management at Mweka in Tanzania, and the University of Ibadan, with assistance from FAO, runs introductory courses in wildlife management and ecology. These programmes may be expanded in the future to cope with increased staff requirements.

The game laws of Nigeria were devised to regulate sport hunting and are not very effective against the year-round hunting for bushmeat which is the major drain on wildlife populations. But the forthcoming revision of the laws will take account of this and should form a basis for implementing modern concepts of management.

The combined area of the game reserves, both gazetted and proposed, exceeds 10,000 square miles. The largest is Borgu covering 1,533 square miles; Yankari covers some 800 square miles, and several of the proposed new reserves are between 500 and 900 square miles. Human habitation is precluded from game reserves by law.

In general, the southern reserves are in the high or secondary forest zone and contain only a limited spectrum of herbivorous animals. Where the forest zone gives way to woodland savanna, as in Upper Ogun and Opara, the habitat is suitable for grazing antelope species such as roan, western hartebeest, waterbuck and kob. Southern savanna woodlands are highly productive of grasses, due to the relatively long rainy season, water is freely available, and thus they have a potentially high carrying capacity. In the drier savanna woodlands of the north, grass production is lower and ground water scarcer. Nevertheless, certain areas support a wide variety of ungulate species, some of them locally abundant.

The Yankari Game Reserve is the most highly developed. Since 1962 when it was opened to the public, there has been a steady increase in the large-mammal biomass. Visitors can now see elephant, buffalo, roan, western hartebeest, waterbuck, bushbuck, oribi, Grimm's duiker, warthog and baboon, and, with luck, also hippopotamus and a number of other species. Between 2000 and 2500 people visit these reserves each year, 90 per cent of them expatriates and their families temporarily resident in the country. Tourist facilities include thatched rondavels, a restaurant and a swimming pool developed from a natural warm spring.

Borgu Game Reserve, also open to visitors, is about 20 miles from New Bussa, where there is air-conditioned hotel accommodation. A 
visitors' camp is being built inside the reserve on the Oli River. The eastern boundary of Borgu is contiguous with the recently formed Kainji Lake, and the development of recreational facilities such as fishing, bathing, boating and water-skiing are obvious possibilities. Borgu contains the same major herbivores as are found in Yankari together with a good population of kob. Lion and leopard occur and a school of hippopotamus can be seen at the Hippo Pool throughout the dry season. The large mammals appear to be increasing; and in a few years this reserve should provide good game viewing opportunities. Once the animals inside the reserve have increased and expanded their range it may be feasible to allow tourist hunting or cropping for protein in the sparsely populated woodland surrounding it.

An international tourist circuit linking Yankari and Borgu with Waza in the Cameroun, Pendjari in Dahomey and the Parc du W astride the Dahomey/Niger border should be possible, and later, when northern reserves such as Kogin Kano and Gusau-Kwiabana are developed and game animals increased, Nigeria may have its own circuit for tourists.

\section{Major Game Animals}

It is impossible to make a quantitative assessment of the status of wildlife in Nigeria because of the lack of data; this survey relies on the authors' work and various reports by forestry officers and others with wildlife experience. We hope that future research will provide a sound basis for management. With minor exceptions, the nomenclature adopted here follows that of Dorst and Dandelot (1970).

\section{Elephant Loxodonta africana.}

Though nowhere abundant, elephant occur throughout Nigeria, and their status appears to be satisfactory. Village hunters are generally afraid of them, the meat is not highly prized in all areas, and elephant are difficult to kill with the muzzle-loading 'Dane guns' commonly used. The major threat comes from persistent ivory hunters and from farmers claiming crop damage and requesting control. The forest race L.a.cyclotis is restricted to the south; intergrades and the savanna race L.a.africana occur in the middle latitudes and the north. Herds of 30 to 40 are commonly observed in Yankari, and small groups occur in most other parts of the North-Eastern State, notably on the shoreline of Lake Chad and along the rivers that feed the lake; they are perhaps less common in the north-west. In Borgu, elephant are not uncommon and are usually encountered in groups of up to a dozen individuals. They range widely over the reserve and are resident both within it and in areas to the south and east including the Moshi Forest Reserve. They have been recorded recently in most other savanna reserves.

\section{Hippopotamus Hippopotamus amphibius.}

Both range and numbers are much depleted, and without total and effective protection it is doubtful if their status can be significantly improved. Even if hunting were stopped, the extension of their present range would be extremely slow, so it is unlikely that hippopotamus will be managed as a source of protein in the near future. Their current value is mainly as a visitor attraction in game reserves. They occur in small numbers in Yankari and a number of other reserves, including 
some of those in the south, and on the Oli river in Borgu. During the dry season, when the Oli becames a series of permanent pools, the hippopotamus are concentrated and regularly seen. There are frequent complaints from farmers in the North Eastern State alleging crop damage by hippopotamus, but it is doubtful if their abundance anywhere leads to raiding of farmlands on a significant scale.

The status of the pygmy hippopotamus Choeropsis liberiensis is not clear; no adequate survey had been made in the Niger Delta. If it exists it is extremely rare.

Manatee Trichechus senegalensis.

Generally restricted to the main Niger/Benue river system, the manatee is occasionally reported from smaller streams and swamps of the coastal region. Highly prized for its meat, it has been hunted close to extinction in many parts of West Africa. Recently fishermen have caught manatee in Kainji Lake, and it is hoped that this new impoundment may provide suitable conditions for its increase and conservation.

\section{Giraffe Giraffa camelopardalis.}

This totally protected species can still be found in several discrete locations in northern Nigeria, though not in any currently gazetted game reserve. Poachers usually leave them alone as it is very difficult to sell the meat without detection, and the fines imposed on offenders are equal to many months' earnings. They occur in Kogin Kano and should increase there once this proposed reserve is effectively managed. Yankari does not meet their habitat requirements, and the occasional wanderers seen there appear to belong to a group which normally ranges an area some miles to the south.

Buffalo Syncerus caffer.

Although typical specimens of the relatively small forest buffalo S.c.nanus occur in southern Nigeria, the animals of the middle and northern latitudes generally conform to the Sudan buffalo S.c. brachyceros. In body size the buffalo of northern Nigeria are little different from the East African races, though their horns are generally less massive.

In Yankari it is not unusual to find buffalo ranging in herds of up to 100. In Borgu they are still extremely shy and generally encountered in small groups, though a herd of 50 has been seen on a few occasions recently. There are recurring reports of buffalo from all parts of northern Nigeria, but it is unlikely that any really substantial populations exist outside the game reserves. Probably small herds persist along the permanently flowing streams wherever hunting pressures are not too severe.

No reliable information exists on the status of the forest buffalo, although their presence is confirmed in a number of forest reserves and proposed game reserves on both sides of the Niger. Buffalo meat is much sought after, and, as the species appears when protected to be highly productive, it may be utilised in the future for cropping. 
Compared with cattle, the buffalo of northern Nigeria maintain weight remarkably well throughout the dry season and appear to be resistant to tsetse-borne diseases.

Western Hartebeest Alcelaphus buselaphus.

This savanna-living species is the most abundant antelope in Yankari, ranging the drier sections in herds of 5 to 30 individuals. It is common in Borgu, where the population is vigorous and expanding, and is found in adjacent areas, particularly to the south. In Borgu several herds may be seen in close proximity to one another on the new flushes of grass brought on by dry-season bush fires. They also occur in several of the proposed reserves including Opara, in Western State, and small numbers still persist in unprotected areas north of the forest zone. But both range and numbers are well below their potential in Nigeria, and, since western hartebeest utilise woodland savanna areas many miles from water, they would not conflict with domestic animal husbandry.

\section{Topi Damaliscus korrigum.}

The habitat requirements of topi do not wholly coincide with those of western hartebeest, the former generally preferring more open terrain or extensive floodplains. In Waza National Park, Cameroun, for instance, topi are common whereas western hartebeest are rare; in Yankari the situation is reversed and topi have been recorded there only very occasionally. They are absent from Borgu, though there are reports of them in other parts of north-western Nigeria. They have never ranged as far south in the woodland savannas as have the western hartebeest.

Roan Antelope Hippotragus equinus.

The status of this large savanna antelope in Nigeria gives much cause for concern. It appears to be rare and with discontinuous distribution throughout most of the northern regions. Roan occur in Yankari, but calf production is low and general condition often poor. In contrast, they are common in Borgu, where in 1970 a large proportion of young animals were noted and the population appears to be increasing.

\section{Waterbuck Kobus defassa.}

The overall range of waterbuck in Nigeria is greater than that of the three foregoing species. Though restricted to locations with permanent water supplies, they occur in all regions as far south as Orle River game reserve in Mid-Western State. Populations are generally small, except in Yankari where they are abundant along the Gaji river. Being particularly tame, the Yankari waterbuck can be readily seen and photographed throughout the dry season. In Borgu they occur along the Oli river, and also on the larger rivers which drain into Kainji Lake.

\section{Buffon's Kob Kobus kob.}

Kob occur along the margins and floodplains of many permanently flowing streams in the savanna regions. They are particularly common in Borgu, along the Oli river and its larger tributaries, where they are becoming increasingly accustomed to vehicles and may be watched and photographed. In Upper Ogun, they are also common and herds of 50 
or more may be encountered. They appear to be highly productive and, given adequate protection, should recover rapidly from earlier depletion. They are ideal for game viewing since they are quite tame and favour open grassy locations. Although they occur in many areas of northern Nigeria, they are absent from Yankari due to the lack of suitable habitat.

\section{Reedbuck Redunca redunca.}

Infrequently seen, since they normally live singly or in pairs in dense reedbeds and riparian grasslands, reedbuck are far less common than kob and many hunters have never seen one. They occur in Borgu but are more numerous in the more favourable conditions to the west. The effect on the shoreline vegetation of the annual 'draw-down' of Kainji Lake may create new habitat for reedbuck.

Bushbuck Tragelaphus scriptus.

Nowhere abundant, but widely distributed, bushbuck occur in secondary forest in many of the southern reserves and in dense riparian woodlands in northern savanna areas. They can be readily seen in Yankari, Borgu, Upper Ogu and Opara.

Sitatunga Tragelaphus spekei.

Due to its highly specialised habitat requirements, sitatunga has a very limited distribution. It occurs in a number of swampy areas of the south and on both sides of the Niger. The nature of its habitat may prevent serious over-hunting, although its meat may be seen for sale quite frequently in southern markets. There are occasional reports of sitatunga along the Lake Chad shoreline, but its numbers there are much reduced.

\section{Water Chevrotain Hyemoschus aquaticus.}

This curious ungulate, occupying similar habitat to the sitatunga, occurs only in the swamps of the southern forest zone. Its current status is quite unkown though reports confirm its existence on both sides of the Niger.

Klipspringer Oreotragus oreotragus.

Confined to rocky locations on the Jos Plateau, this is the most westerly klipspringer population in Africa, separated from the nearest population to the east by more than 1000 miles of largely unfavourable habitat. This unique antelope appears to be depleted and in need of effective conservation.

Oribi Ourebia ourebi.

Widely distributed north of the forest zone, oribi are common in both Yankari and Borgu and probably occur in all the proposed savanna reserves. Though found singly or in family groups, they appear to be quite productive and survive in heavily hunted areas.

\section{Duikers}

Duikers provide a very large proportion of the bushmeat sold in 
southern Nigeria, and despite incessant hunting most species appear to be in no danger of extinction. Production and population turn-over are undoubtedly high due to their early maturation, the absence of an annual breeding season and a relatively short gestation period. But their populations are probably well below optimum levels in areas accessible to hunters.

Black duiker Cephalophus niger and Maxwell's duiker $C$. monticola appear to be restricted to the southern forest zone to the west of the Niger; whereas the bay duiker $C$. dorsalis and the relatively large yellow-backed duiker $C$. silvicultor are confined to forest habitat on the eastern side of the Niger close to the Cameroun border. Red-flanked duiker $C$. rufilatus occur on both sides of the Niger and in forest habitat fringing many rivers in the middle and northern latitudes. In Borgu they are regularly seen along the Oli river, particularly after the annual bush fires. Grimm's duiker Sylvicapra grimmia, common in both Yankari and Borgu, is the only true savanna species found in dry semi-open woodland, obtaining the moisture it needs from the leaves of the shrubs that constitute much of its diet.

\section{Gazelles}

Both dorcas gazelle Gazella dorcas and dama gazelle G. dama occurred formerly in the Lake Chad region in the sahelian savanna type. Since this area approximates the southern limit of the range of both species and since hunting pressures have increased in the north-east in recent years, the status of both species in Nigeria should be regarded as rare and insecure at best. The red-fronted gazelle $G$. rufifrons ranges further to the south, finding suitable habitat in the northern Guinea savanna types. Formerly quite common, they occured in sizable herds close to many townships in northern Nigeria, but are now much depleted and rarely encountered in groups of more than three or four. Extremely rare in Yankari, it was recorded there in 1970.

\section{Wild Pigs}

Forestry officers report the continuing existence of the bush-pig Potamochoerus porcus in some high and secondary forest areas of the south-east, but it is probably far less abundant than in nearby areas of Cameroun. In contrast, warthog Phacochoerus aethiopicus are found throughout the savanna regions, largely as a result of religious objection to their meat. In Yankari they are abundant close to the Gaji river and fairly common even in drier areas of the reserve, generally producing litters of $6-8$, which predation and other mortality factors normally reduce to $2-4$ within the first month or so. In Borgu, where they are common and widely distributed, there is a high proportion of young animals, and they are becoming increasingly less shy; they are also found in uninhabited areas outside the reserve. They occur in limited numbers in all the proposed reserves of northern Nigeria.

\section{Primates}

As many as 16 primate species have been recorded in recent decades, but some, including gorilla Gorilla gorilla and chimpanzee Pan troglodytes, must now be regarded as extremely rare. The gorilla may be 
extinct, or close to extinction, despite its continuing presence across the border in southern Cameroun.

Most commonly encountered are the mona monkey Cercopithecus mona of the high forest region and the patas monkey Erythrocebus patas, a large terrestrial species which ranges the drier savannas. The green or tantalus monkey $C$. aethiops is quite common in many areas north of the high forest zone but is normally restricted to woodlands fringing permanently flowing streams. The handsome black and white colobus monkey Colobus polykomos, though nowhere abundant, occurs in the southern forest zone.

The anubis baboon Papio anubis - the largest baboon in Africa - is the commonest primate north of the forest zone, where it is widely though often sparsely distributed. It is abundant in Yankari, and very common in Borgu, occurring in troops of 5.0 or more.

\section{Predators}

The high price of their skins has resulted in a marked reduction in the numbers and distribution of the larger carnivores. Leopard Panthera pardus and, to an even greater extent, cheetah Acinonyx jubatus are now extremely rare, though the former is not uncommon in Borgu. Genets Genetta spp., the civet Viverra civetta and the serval Felis serval are hunted and trapped throughout the year wherever they occur. The caracal Felis caracal, of the northernmost savannas, and the golden cat Felis aurata, of the high and secondary forest regions, appear to be close to extinction in Nigeria since the skin of either is considered an extreme rarity.

Species whose skins have little or no commercial value, such as the side-striped jackal Canis adustus and the spotted hyena Crocuta crocuta, receive less attention from hunters and have been recorded fairly frequently in recent years in a number of savanna areas, including Yankari. In Borgu hyena are sometimes seen in the late evening or early morning and are often heard calling in the vicinity of the proposed visitor's camp.

Lion Panthera leo were regarded as uncommon in Nigeria as early as the first part of this century. They persist in small numbers throughout the north, a few being shot each year. In Borgu sightings have increased during the past year, a welcome trend which should continue as they become accustomed to motor vehicles. They occur in Yankari and some proposed reserves in the north, though the casual visitor is unlikely to see one.

Perhaps the commonest predator of the savannas is the wild hunting dog Lycaon pictus. In Yankari packs of up to a dozen are seen from time to time, and in Borgu up to 30 have been seen recently. There are continuing reports of their occurrence in other areas where adequate ungulate populations exist.

\section{References}

CHARTER, J., 1970. The Economic Value of Wildlife in Nigeria. 1st Ann.Conf ., For.Assoc., Nig.Mimeo., 12pp.

DORST, J., and P. DANDELOT, 1970. A Field Guide to the Larger Mammals of Africa. Collins, London, $287 \mathrm{pp}$. 


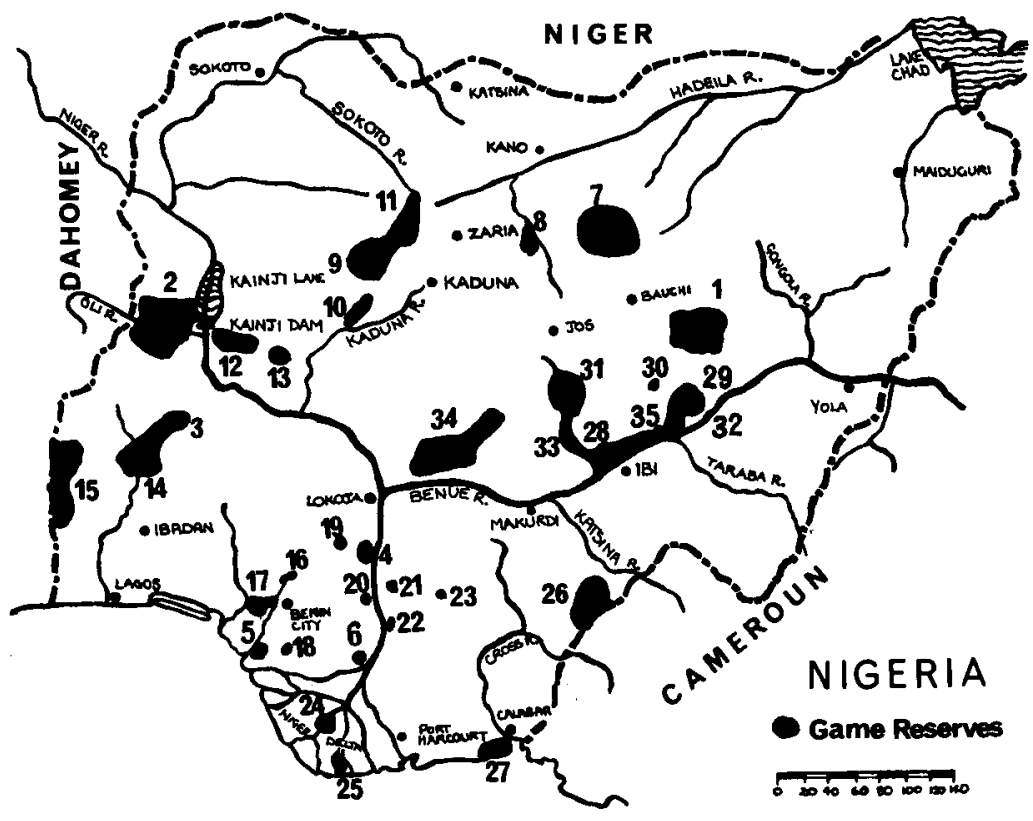

Constituted Game Reserves*

1 Yankari, North-Eastern State

2 Borgu, Kwara

3 Old Oyo, Western

4 Orle River, Mid-Western

$5 \mathrm{Kw}$ ale, Mid-Western

6 Gilli-Gilli, Mid-Western

\section{Proposed Game Reserves}

7 Lame, North-Eastern

8 Kogin Kano, Kano

9 Kamuku, North-Central

10 Alava, North-Western

11 Gusau-Kwiambana, North-Western

12 Zugurma, North-Western

13 Dagidda, North-Western

14 Upper Ogum, Western

15Opara, Western

16 Ohasu, Mid-Western

17 Okomu, Mid-Western

18 Ologbo, Mid-Western

19 Ivi-Ada-Obi, Mid-Western

20 Ologholo-Emu-Urho, Mid-

Western

21 Anambra, Mid-Western

22 Akpapa, Mid-Western
23 Udi/Nsukka, Mid-Western

24 Game Reserve 'A' Rivers

25 Game Reserve 'B' Rivers

26 Obudu, South-Eastern

27 Stubbs Creek, South-Eastern

$28 \mathrm{Ibi}$, Benue-Plateau

29 Wase Game Sanctuary, Benue-Plateau

30 Wase Rock Bird Sanctuary, Benue-Plateau

31 Pandam Wildlife Park, BenuePlateau

32 Pai River, Benue-Plateau

33 Ankwe River, Benue-Plateau

34 Nasarawa, Benue-Plateau

35 Dampar Sanctuary, BenuePlateau

* Since the map was drawn the four game reserves numbered $10-13$ have been constituted, making a total of ten, with 25 in various stages of negotiation 